US Army Corps

of Engineers ${ }_{\circledast}$

Engineer Research and

Development Center

Aquatic Plant Control Research Program

Comparison of Generic and Proprietary Aquatic Herbicides for Control of Invasive Vegetation: Part 1. Floating Plants

Christopher R. Mudge and Kurt D. Getsinger 
The U.S. Army Engineer Research and Development Center (ERDC) solves the nation's toughest engineering and environmental challenges. ERDC develops innovative solutions in civil and military engineering, geospatial sciences, water resources, and environmental sciences for the Army, the Department of Defense, civilian agencies, and our nation's public good. Find out more at www.erdc.usace.army.mil.

To search for other technical reports published by ERDC, visit the ERDC online library at http://acwc.sdp.sirsi.net/client/default. 


\section{Comparison of Generic and Proprietary Aquatic Herbicides for Control of Invasive Vegetation: Part 1. Floating Plants}

Christopher R. Mudge

U.S. Army Engineer Research and Development Center

Environmental Laboratory

Louisiana State University

108 MB Sturgis Hall

Baton Rouge, Louisiana 70803

Kurt D. Getsinger

Environmental Laboratory

U.S. Army Engineer Research and Development Center

3909 Halls Ferry Road

Vicksburg, MS 39180-6199

Final Report

Approved for public release; distribution is unlimited.

Prepared for Headquarters, U.S. Army Corps of Engineers

Washington, DC 20314-1000

Under Project number 462030 


\section{Abstract}

Herbicides are one of the most effective and widespread ways to manage nuisance aquatic vegetation in the U.S. After the active ingredient is selected, often there are multiple proprietary and generic branded products to choose from. Limited research has been conducted to compare the efficacy of these herbicides head to head. Therefore, a series of mesocosm trials were conducted to evaluate $2,4-\mathrm{D}$, glyphosate, diquat, and triclopyr against the floating species giant salvinia, water hyacinth, and water lettuce. All active ingredients were applied to the foliage at broadcast rates commonly used in applications to public waters. Visual observations indicated that all herbicides within a particular active ingredient performed similarly with regard injury symptoms. There were no significant differences in product performance with regard to 2,4-D vs. water hyacinth, diquat vs. water lettuce, glyphosate vs. giant salvinia, and triclopyr vs. water hyacinth. Although statistical differences in performance of products were detected in the diquat vs. water lettuce (trial 3) and both glyphosate vs. water hyacinth trials, these differences were not consistent across initial and repeated trials. These results demonstrated that under outdoor mesocosm conditions, the majority of the generic and proprietary herbicides provided similar control, regardless of active ingredient or rate.

DISCLAIMER: The contents of this report are not to be used for advertising, publication, or promotional purposes. Citation of trade names does not constitute an official endorsement or approval of the use of such commercial products. All product names and trademarks cited are the property of their respective owners. The findings of this report are not to be construed as an official Department of the Army position unless so designated by other authorized documents.

DESTROY THIS REPORT WHEN NO LONGER NEEDED. DO NOT RETURN IT TO THE ORIGINATOR. 


\section{Contents}

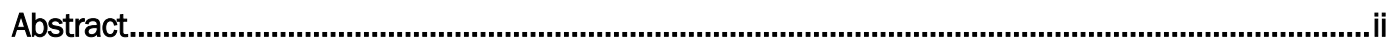

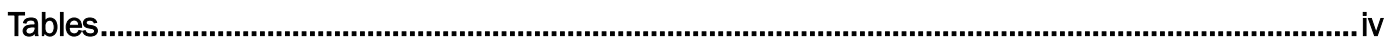

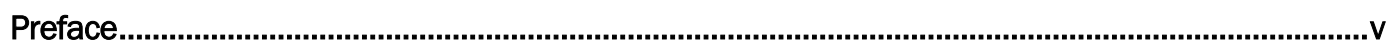

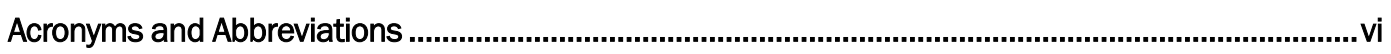

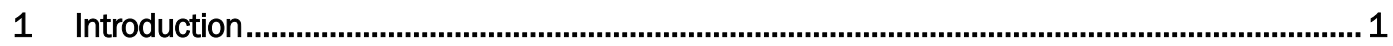

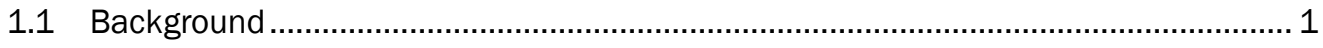

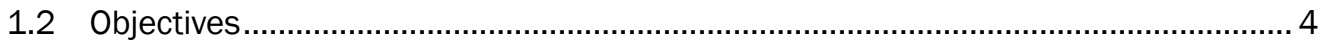

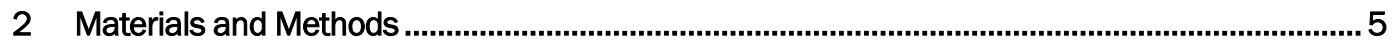

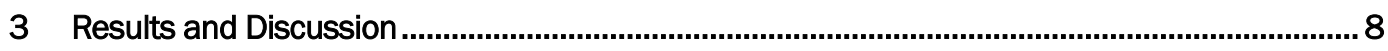

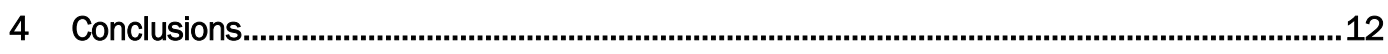

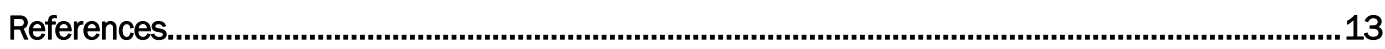

Report Documentation Page 


\section{Tables}

Table 1. Generic brand and proprietary brand aquatic herbicides trade name, active ingredient, and manufacturer of products evaluated against floating plants.

Table 2. Generic brand and proprietary brand aquatic herbicides evaluated against floating plants.

Table 3. Efficacy (mean g dry weight, \pm SE) of generic and proprietary aquatic 2,4-D brands against water hyacinth 8 WAT ${ }^{\text {. }}$.

Table 4. Efficacy (mean $g$ dry weight, $\pm \mathrm{SE}$ ) of generic and proprietary aquatic diquat brands against giant salvinia and water lettuce eight weeks after treatmenta.

Table 5. Efficacy (mean g dry weight, \pm SE) of generic and proprietary aquatic glyphosate brands against giant salvinia and water hyacinth eight weeks after treatmenta.

Table 6. Efficacy (mean g dry weight, \pm SE) of generic and proprietary aquatic triclopyr brands against water hyacinth three weeks after treatmenta. 


\section{Preface}

This study was conducted as part of the Aquatic Plant Control Research Program (APRCP). The APCRP is sponsored by Headquarters, U.S. Army Corps of Engineers (HQUSACE), and is assigned to the U.S. Army Engineer Research and Development Center (ERDC) under the purview of the Environmental Laboratory (EL), Vicksburg, MS. Funding for the APCRP was provided under the Department of the Army Appropriation Number 96x3122, Construction General.

The work was performed by the Aquatic Ecology and Invasive Species (EEA) of the Ecosystem Evaluation and Engineering Division (EE), U.S. Army Engineer Research and Development Center, Environmental Laboratory (ERDC-EL). At the time of publication, Dr. Timothy Lewis was Chief, CEERD-EEA; Mr. Mark D. Farr was Chief, CEERD-EE; and Dr. Alfred Cofrancesco, CEERD-EZT was the Technical Director for the Civil Works Environmental Engineering and Sciences Office. The Deputy Director of ERDC-EL was Dr. Jack E. Davis and the Director was Dr. Ilker R. Adiguzel.

COL Teresa A. Schlosser was Commander of ERDC, and Dr. David W. Pittman was the Director. 


\section{Acronyms and Abbreviations}

\begin{tabular}{|l|l|}
\hline Acronym & \multicolumn{1}{|c|}{ Meaning } \\
\hline AARF & AgCenter Aquaculture Research Facility \\
\hline ANOVA & analysis of variance \\
\hline APCRP & Aquatic Plant Control Research Program \\
\hline DAT & Days After Treatment \\
\hline DoD & Department of Defense \\
\hline EL & Environmental Laboratory \\
\hline ERDC & Engineer Research and Development Center \\
\hline g & grams \\
\hline km & kilometers \\
\hline L & Liter \\
\hline LSU & Louisiana State University \\
\hline SON & Statement of Need \\
\hline U.S. & United States \\
\hline USACE & U.S. Army Corps of Engineers \\
\hline USEPA & U.S Environmental Protection Agency \\
\hline WAT & Weeks after treatment \\
\hline
\end{tabular}




\section{Introduction}

\subsection{Background}

Invasive submersed, floating, and emergent aquatic plants are continuously introduced into the United States (U.S.), negatively impacting U.S. Army Corps of Engineer (USACE), state, and private water bodies. Nuisance aquatic vegetation disrupts waterborne transportation, blocks potable water and irrigation intakes, degrades water quality, and displaces native plant and wildlife communities, including critical habitat for listed species (Getsinger et al. 2014). Chemical control, through the use of registered aquatic herbicides, is a technique that is widely employed by aquatic plant managers in the U.S. (Netherland 2014). Aquatic herbicides registered by the U.S. Environmental Protection Agency (USEPA) have been used to prevent further spread and provide control of existing populations of invasive plants. In general, herbicides are selected for a high-level of efficacy against the target species, possess relatively short aqueous half-lives, and have limited impacts on non-target/native plant species (Mudge 2007).

The standard herbicide registration has a 17-year patent for proprietary rights for brand name, formula, inert ingredients, and production of the proprietary brand-name or trademark product when it is initially registered (McFalls et al. 2015). After this period ends, other companies can synthesize/manufacture or distribute the herbicide under a different name (i.e., off-patent herbicide) (McFalls et al. 2015), commonly referred to as "generic" products (or "me-too" labels), using the original registration data. These generic products also have branded names, though different than the original, proprietary brand names. Although there are only 15 active ingredients registered for aquatic sites by the USEPA for Nation-wide use (Section 3 Registration) (Netherland and Jones 2012; University of Florida 2018), there are multiple registrants selling off-patent generic herbicides under a variety of branded names. In particular, end users have a large selection of available generic options when choosing some of the key legacy chemicals (e.g., 2,4-D, glyphosate, and diquat). However, many of the more recently registered proprietary aquatic herbicides do not have a generic counterpart because original patent life has not expired, or due to the cost or difficulty to manufacture the active ingredients. 
There are advantages and disadvantages to using proprietary or generic aquatic herbicides. Often, proprietary herbicide manufacturers provide a wide range of customer/product support services and some level of product warranty to protect the end-user for rare cases of unacceptable performance. In addition, familiarity with proprietary products, well documented performance in the field, and/or manufacturer recognition are selling points to the end user. Conversely, proprietary herbicides may come with added expenses, even after patent expiration. Proprietary registrants must recover high costs associated with initial discovery, development, registration, and marketing expenses over an extended period due to the relatively minor market-share for aquatic herbicides. In addition, the USEPA requires a comprehensive registration review process every 15 years for all products seeking to maintain existing registrations (USEPA 2017). In most cases, the effort and costs associated with this process are heavily underwritten by the proprietary registrant.

Alternatively, generic products generally have a lower initial investment than their proprietary counterpart (McFalls et al. 2015), since the generic manufacturer does not pay the full cost of product development and/or registration. Lower initial investment costs allows these products to be offered at a lower market price. Moreover, some generic manufacturers provide little to no customer/product services, which also impacts market price. However, the generic product may carry a negative connotation/stigma of being an inferior product, even though it has the same active ingredient and percent composition as the proprietary herbicide. To be used as a viable alternative, most managers believe that a generic counterpart should deliver the same, or similar level of performance (i.e., efficacy) as the proprietary herbicide. Although active ingredient disclosure is required by the USEPA, non-pesticidal inert or inactive ingredients such as solvents, stabilizers, emulsifiers, surfactants and other additives can vary among products and are considered proprietary information. Inert active ingredients of products must be reported to the USEPA, and they are evaluated for potential impacts to human health and the environment.

Limited research has been conducted to evaluate the efficacy of generic herbicides alone, or direct comparisons of generic vs. proprietary aquatic herbicides. Previous research comparing generic vs. proprietary aquatic herbicides has focused on subsurface applications of fluridone (1-methyl3-phenyl-5-[3-(trifluoromethyl)phenyl]-4(1H)-pyridinone) and copper 
(Langeland et al. 2002; Koschnick et al. 2003; Poovey et al. 2004; Bultemeier et al. 2009; Turnage et al. 2015). Similarly, agriculture research has evaluated foliar applications of glyphosate, triclopyr, clopyralid (3,6-dichloro-2-pyridinecarboxylic acid), glufosinate (2-amino4-(hydroxymethylphosphinyl)butanoic acid), and metsulfuron-methyl (2-[[[[(4-methoxy-6-methyl-1,3,5-triazin-2-

yl)amino]carbonyl]amino]sulfonyl]benzoic acid) for efficacy against a variety of weed species (Hinklin et al. 2002; Cadenhead et al. 2007; Siekman and Sandell 2008; Latiff et al. 2009;). The limited data directly comparing herbicide performance in an aquatic setting has forced managers to rely on product name brand recognition, as well as anecdotal evidence when selecting an herbicide. Often, the resource manager or practitioner does not know if the chosen product is as effective as other available options, as well as if the product provides any added management values or benefits. In addition, there is considerable procurement pressure applied on, and by, public agencies to utilize the "lowest bid" for selection of herbicide brands that may ignore product performance and "valued-added" customer service by the registrant. Because of the sensitive nature of applying pesticides to surface waters, resource managers must ensure that products perform as advertised, and protection of the public and the environment is maintained.

Due to the limited amount of empirical evidence directly comparing performance of identical active ingredients, research is needed to fully understand the scope of generic herbicide utility. Over the past decade, these comparative evaluations have been requested by several USACE districts and state agencies searching for technical guidance for potential use of generic products in operational control programs in public waters. In FY16, the SAJ formally submitted a statement of need (SON) through the USACE's Aquatic Plant Control Research Program (APCRP) to compare efficacy of generic vs. proprietary herbicides and determine their utility as a viable option for managing aquatic vegetation in public waterways. In the era of annual budget uncertainties and the proliferation of generic labels, key stakeholders need data on head-to-head efficacy comparisons in order to make informed and cost-effective management decisions. Once resource managers fully understand any differences between proprietary and generic products they can make more informed performance and procurement decisions in the best interests of the public, while adequately controlling invasive aquatic vegetation. 
As the first of a three-part series, this document provides results on the efficacy of selected proprietary and generic products used to manage invasive floating emergent and submersed vegetation. Plant species, products, and application rates were selected based on extensive discussions with key UASCE District and state personnel responsible for managing invasive aquatic plants. Subsequent evaluations will compare proprietary and generic product performance on invasive submersed vegetation, and rooted emergent vegetation.

\subsection{Objectives}

The objectives of this research were to (1) to evaluate the efficacy of commonly used herbicides, both generic and proprietary products, for controlling key floating aquatic plants found throughout the U.S. in a small-scale mesocosm setting, and (2) determine if differences exist between generic and proprietary product performance. 


\section{Materials and Methods}

A series of outdoor, replicated mesocosm trials were conducted at the Louisiana State University (LSU) AgCenter Aquaculture Research Facility (AARF) in Baton Rouge, LA, to evaluate the efficacy of generic and proprietary 2,4-D, glyphosate, diquat, and triclopyr against giant salvinia, water hyacinth, and water lettuce. Both generic and proprietary herbicides commonly used by USACE districts and state agencies against problematic floating aquatic plants were evaluated. The trials were conducted from December 2016 through September 2017. All plants were collected from cultures maintained at LSU AARF or University Lake, Baton Rouge, LA. Within a given trial and plant species, equal amounts of fresh plant material were placed inside 76 Liter (L) plastic containers $(49.5 \mathrm{~cm}$ diameter by $58.4 \mathrm{~cm}$ height). Containers were filled with water ( $\mathrm{pH} 8.0-$ 8.5) collected from ponds at LSU AARF and amended with Miracle-Gro ${ }^{\circledR}$ Lawn Fertilizer (The Scotts Company, Marysville, OH) (36-6-6, 41.6 mg L1) initially and four weeks after herbicide treatment. Tanks with giant salvinia were amended with sphagnum moss (30 grams (g) dry material per tank) to lower the water $\mathrm{pH}$ to $<7$, to simulate favorable growth conditions for that species. Water level was maintained weekly at $60 \mathrm{~L}$ by the addition of pond water. Air temperature data were provided from the LSU AgCenter Central Research Station, 1.6 kilometers $(\mathrm{km})$ to the east of the mesocosm location (LSU AgCenter 2017).

Plants were allowed to acclimate under experimental conditions for 1-2 weeks prior to herbicide application, and were in a healthy and active growing state at time of treatments. Herbicides were applied to foliage at broadcast rates commonly used in applications to public waters (Table 1 and Table 2). All herbicides within a given trial were applied at the same $g$ acid equivalent (a.e.) or active ingredient (a.i.) ha-1 regardless of $g$ a.e. $\mathrm{L}^{-1}$ or $\mathrm{g}$ a.i. $\mathrm{L}^{-1}$ within each container. A non-ionic surfactant (Surf-AC ${ }^{\circledR}$ 910, Drexel Chemical Company, Memphis, TN) at the equivalent of $0.25 \% \mathrm{v} / \mathrm{v}$ was included with all treatments. An untreated control was also included with each trial to compare plant growth in the absence of herbicide. Treatments were randomly assigned and replicated five times and all trials were conducted 2 or 3 times. Herbicides were applied to plants using a forced air $\mathrm{CO}_{2}$-powered sprayer at an equivalent of $935 \mathrm{~L} \mathrm{ha}^{-1}$ diluent delivered through a single TeeJet ${ }^{\circledR}$ (Spraying Systems Company, Wheaton, IL) 80-0067 nozzle at $20 \mathrm{psi}$. This application technique provided even coverage of herbicides over the leaf and shoot surfaces. 
At 1-8 weeks after treatment (WAT), all viable plant material was harvested, dried at $65{ }^{\circ} \mathrm{C}$ to a constant weight, and dry weight biomass was determined. Biomass data were analyzed using an analysis of variance (ANOVA) and if differences were detected, means were separated using Fisher's Protected LSD $(\mathrm{p} \leq 0.05)$. If applicable, data were pooled across repeated trials if no differences between repetitions were detected $(\mathrm{p} \leq$ 0.05).

Table 1. Generic brand and proprietary brand aquatic herbicides trade name, active ingredient, and manufacturer of products evaluated against floating plants.

\begin{tabular}{|c|c|c|c|}
\hline Trade Name & Active Ingredient & Manufacturer & Address \\
\hline 2,4-D Amine & 2,4-D & Alligare, LLC, & Opelika, AL \\
\hline DMA $® 4$ IVM & 2,4-D & Dow AgroSciences LLC & Indianapolis, IN \\
\hline Shredder ${ }^{\circledR}$ Amine & 2,4-D & Winfield Solutions, LLC & St. Paul, MN \\
\hline WEEDestroy ${ }^{\circledR}$ AM-40 & 2,4-D & Nufarm Americas Inc & Burr Ridge, IL \\
\hline Weedar ${ }^{\circledR} 64$ & 2,4-D & Nufarm Americas Inc. & Burr Ridge, IL \\
\hline Rodeo $\AA$ & glyphosate & Dow AgroSciences LLC & Indianapolis, IN \\
\hline Roundup Custom ${ }^{\mathrm{TM}}$ & glyphosate & Monsanto Company & St. Louis, MO \\
\hline AquaPro ${ }^{\circledR}$ & glyphosate & SePRO Corporation & Carmel, IN \\
\hline AquaNeat ${ }^{\circledR}$ & glyphosate & Nufarm Americas Inc. & Burr Ridge, IL \\
\hline Refuge $^{T M}$ & glyphosate & $\begin{array}{l}\text { Syngenta Crop } \\
\text { Protection }\end{array}$ & Greensboro, NC \\
\hline Glyphosate 5.4 & glyphosate & Alligare LLC & Opelika, AL \\
\hline Reward $\AA$ & diquat & $\begin{array}{l}\text { Syngenta Crop } \\
\text { Protection }\end{array}$ & Greensboro, NC \\
\hline Tribune $^{\mathrm{TM}}$ & diquat & $\begin{array}{l}\text { Syngenta Crop } \\
\text { Protection }\end{array}$ & Greensboro, NC \\
\hline Littora $®$ & diquat & SePRO Corporation & Carmel, IN \\
\hline Diquat SPC $2 \mathrm{~L}$ & diquat & Nufarm Americas Inc. & Burr Ridge, IL \\
\hline Weedtrine ${ }^{\circledR} \mathrm{D}$ & diquat & Applied Biochemists & Alpharetta, GA \\
\hline Diquat & diquat & Alligare LLC & Opelika, AL \\
\hline Tsunami DQ ${ }^{\circledR}$ & diquat & Sanco Industries, Inc. & Fort Wayne, IN \\
\hline Harvester ${ }^{\circledR}$ & diquat & Applied Biochemists & Alpharetta, GA \\
\hline Renovate $\AA 3$ & triclopyr & SePRO Corporation & Carmel, IN \\
\hline Garlon $\circledast 3 A$ & triclopyr & Dow AgroSciences LLC & Indianapolis, IN \\
\hline Triclopyr 3, & triclopyr & Alligare LLC & Opelika, AL \\
\hline Trycera ${ }^{\circledR}$ & triclopyr & $\begin{array}{l}\text { Helena Chemical } \\
\text { Company }\end{array}$ & Collierville, TN \\
\hline
\end{tabular}


Table 2. Generic brand and proprietary brand aquatic herbicides evaluated against floating plants.

\begin{tabular}{|c|c|c|c|}
\hline Active Ingredient & Products ${ }^{a, b}$ & Rates $\left(g \text { a.e. }{ }^{c} \text { ha }^{-1}\right)^{d}$ & Plants Evaluated \\
\hline 2,4-D & $\begin{array}{l}\text { Weedar 64, 2,4-D Amine, DMA } 4 \text { IVM, } \\
\text { Shredder Amine, WEEDestroy AM-40 }\end{array}$ & 1598.0 & Water Hyacinth \\
\hline Glyphosate & $\begin{array}{l}\text { Rodeo, Roundup Custom, AquaPro, } \\
\text { AquaNeat, Refuge, Glyphosate } 5.4\end{array}$ & $2242.8,3364.1$ & $\begin{array}{l}\text { Water Hyacinth, } \\
\text { Giant Salvinia }\end{array}$ \\
\hline Diquat & $\begin{array}{l}\text { Reward, Tribune, Littora, Diquat SPC } \\
\text { 2L, Weedtrine D, Diquat, Tsunami DQ, } \\
\text { Harvester }\end{array}$ & $841.0,1682.1$ & $\begin{array}{l}\text { Giant Salvinia, } \\
\text { Water Lettuce }\end{array}$ \\
\hline Triclopyr & $\begin{array}{l}\text { Renovate 3, Garlon 3A, Triclopyr 3, } \\
\text { Trycera }\end{array}$ & 1682.1 & Water Hyacinth \\
\hline
\end{tabular}

a Proprietary herbicides: Weeddar 64, Rodeo, Reward, and Renovate 3.

$\mathrm{b}$ Consult state regulations concerning the use of these products for aquatic sites.

c Abbreviations: a.e., acid equivalent.

d Diquat was applied as g active ingredient (a.i.) ha-1. 


\section{Results and Discussion}

Visual observations indicated that all generic and proprietary herbicides within a given trial and particular active ingredient performed similarly with regard to degree and progression of injury symptoms. Injury symptoms were observed at ca. $<0.5,1,1$, and 5 days after treatment (DAT) for plants treated with diquat, 2,4-D, triclopyr, and glyphosate, respectively. Most plants, except water lettuce treated with diquat (1682.1 $\mathrm{g}$ a.i. ha-1) and water hyacinth treated with triclopyr (1682.1 g a.e. ha-1), recovered from the herbicide treatments between 5 (water lettuce vs. diquat at 841.o g a.i. ha-1) and 28 DAT (water hyacinth vs. 2,4-D at 1598.0 g a.e. ha-1). Plant recovery was expressed as the occurrence of healthy green tissue emerging as new leaves or stems in herbicide treated containers.

The generic 2,4-D products performed similarly with regard to injury symptoms and control provided compared to the proprietary product against water hyacinth in trials 1 and 2 (Table 3). Although the data could not be pooled between trials, product performance differences were not detected. Trial 1 provided $78-95 \%$ control, while trial 2 provided $81-96 \%$ control.

Table 3. Efficacy (mean $g$ dry weight, $\pm \mathrm{SE}$ ) of generic and proprietary aquatic 2,4-D brands against water hyacinth 8 WATa.

\begin{tabular}{|l|l|l|}
\hline Herbicide $^{\mathrm{b}}$ & Trial 1 & Trial 2 \\
\hline Control & $382.4 \pm 77.1 \mathrm{a}^{\mathrm{c}}$ & $163.1 \pm 14.2 \mathrm{a}$ \\
\hline 2,4-D Amine & $83.6 \pm 24.4 \mathrm{~b}$ & $31.5 \pm 15.3 \mathrm{~b}$ \\
\hline DMA 4 IVM & $47.3 \pm 18.1 \mathrm{~b}$ & $6.2 \pm 5.6 \mathrm{~b}$ \\
\hline Shredder Amine & $51.9 \pm 13.3 \mathrm{~b}$ & $14.7 \pm 8.1 \mathrm{~b}$ \\
\hline WEEDestroy AM-40 & $23.1 \pm 11.1 \mathrm{~b}$ & $10.5 \pm 5.6 \mathrm{~b}$ \\
\hline Weedar 64 & $20.7 \pm 10.6 \mathrm{~b}$ & $18.1 \pm 7.8 \mathrm{~b}$ \\
\hline
\end{tabular}

a Pre-treatment weights for trials 1 and 2 were 62.4 and $65.1 \mathrm{~g}$, respectively.

b All herbicides applied at $1598.0 \mathrm{~g}$ acid equivalent (a.e. ha-1).

$c$ Means within a column followed by the same letter are not significantly different according to Fisher's

Protected LSD at $\mathrm{p} \leq 0.05 ; \mathrm{n}=5$.

Diquat provided 98-100\% giant salvinia control in trials 1 and 2 (Table 3). All products provided rapid injury (necrosis) and differences in speed of control were not detected among the eight diquat products evaluated in the mesocosm research. These trials were conducted in December when air temperatures were ca. $58^{\circ} \mathrm{C}$, which fell within the optimal temperature 
range for maximizing diquat efficacy against giant salvinia (Mudge and Sartain 2018). All water lettuce treated with diquat at $1682.1 \mathrm{~g}$ a.i. ha-1 was controlled $100 \%$ at 1 WAT (Table 3 ). The rapid plant death in the initial trial prompted a repeat of this trial at a lower application rate (841.0 $\mathrm{g}$ a.i. ha-1). The lower rate still resulted in $99 \%$ control, and this level of control was confirmed in the third trial at the evaluated rate which resulted in $68-99 \%$ reductions in biomass compared to the untreated reference. Efficacy differences in trial 3 could be the result of seasonal treatment timing, as this trial was conducted in mid-June $\left(29^{\circ} \mathrm{C}\right)$ compared to trials 1 and 2 conducted in late-March and mid-April when average temperatures were $19^{\circ} \mathrm{C}$ and $22{ }^{\circ} \mathrm{C}$, respectively. The cooler temperatures at herbicide application may have resulted in consistently greater control of water lettuce, as plant tissue at that time was young, tender and more susceptible to herbicide uptake. In addition, only one herbicide (Weedtrine-D) provided less control in trial 3, but the product was similar to the others in trial 1 and trial 2 of diquat vs. water lettuce.

Similar to the other trials, there were no differences among the glyphosate products evaluated against giant salvinia as all products provided $85-95 \%$ and $94-99 \%$ in trials 1 and 2, respectively (Table 4 ). The efficacy of diquat (Reward, $\geq 1120$ g a.i. ha-1) and glyphosate (Rodeo, $\geq 2240$ g a.e. ha-1) vs. giant salvinia was previously investigated by Nelson et al. (2001), who documented diquat and glyphosate applied at rates similar and higher to those applied in the current trial, provided $99-100 \%$ control. The results of the current generic/proprietary research support those earlier findings.

Generic and proprietary glyphosate products did show differences when applied to water hyacinth (Table 4). All products were efficacious in the two trials and provided 82-99\% control. In particular, Rodeo provided less control than Glyphosate 5.4 in trial 1, while AquaPro was more efficacious compared to AquaNeat in trial 2. In addition, less control was observed in the second glyphosate vs. water hyacinth trial and could be attributed to time of year trial 1 was treated $\left(\left(7\right.\right.$ April $\left(18^{\circ} \mathrm{C}\right)$, while trial 2 was treated 18 August $\left(94^{\circ} \mathrm{C}\right)$ ). The maturity of plants and rate of growth following treatment could be responsible for decreased efficacy at the higher temperatures during treatments. 
Table 4. Efficacy (mean $g$ dry weight, $\pm S E$ ) of generic and proprietary aquatic diquat brands against giant salvinia and water lettuce eight weeks after treatmenta.

\begin{tabular}{|c|c|c|c|c|c|}
\hline & $\begin{array}{c}\text { Giant Salvinia } \\
\text { Trial } 1^{\mathrm{b}}\end{array}$ & $\begin{array}{c}\text { Giant Salvinia } \\
\text { Trial } 2\end{array}$ & $\begin{array}{c}\text { Water Lettuce } \\
\text { Trial } 1^{c}\end{array}$ & $\begin{array}{c}\text { Water Lettuce } \\
\text { Trial } 2\end{array}$ & $\begin{array}{c}\text { Water Lettuce } \\
\text { Trial } 3\end{array}$ \\
\hline & \multicolumn{5}{|c|}{ Rate (g a.i. ha-1) } \\
\hline Herbicide & \multicolumn{3}{|c|}{1682.1} & \multicolumn{2}{|c|}{841.0} \\
\hline Control & $32.4 \pm 6.6 \mathrm{a}^{d}$ & $26.0 \pm 5.2 b$ & $57.5 \pm 2.5 a$ & $105.0 \pm 1.5 a$ & $107.0 \pm 4.2 \mathrm{a}$ \\
\hline Diquat & $0.6 \pm 0.3 b$ & $0.3 \pm 0.3 b$ & $0.0 \pm 0.0 \mathrm{~b}$ & $0.8 \pm 0.7 b$ & $12.4 \pm 9.2 c$ \\
\hline $\begin{array}{l}\text { Diquat SPC } \\
2 \mathrm{~L}\end{array}$ & $0.0 \pm 0.0 \mathrm{~b}$ & $0.0 \pm 0.0 \mathrm{~b}$ & $0.0 \pm 0.0 \mathrm{~b}$ & $0.3 \pm 0.3 b$ & $17.6 \pm 10.4 b c$ \\
\hline Harvester & $0.8 \pm 0.6 \mathrm{~b}$ & $0.2 \pm 0.2 \mathrm{~b}$ & $0.0 \pm 0.0 \mathrm{~b}$ & $0.4 \pm 0.3 b$ & $19.0 \pm 11.2 b c$ \\
\hline Littora & $0.1 \pm 0.1 b$ & $0.0 \pm 0.0 \mathrm{~b}$ & $0.0 \pm 0.0 \mathrm{~b}$ & $0.2 \pm 0.1 b$ & $1.5 \pm 1.1 \mathrm{c}$ \\
\hline Reward & $0.1 \pm 0.1 b$ & $0.2 \pm 0.1 b$ & $0.0 \pm 0.0 \mathrm{~b}$ & $0.2 \pm 0.0 \mathrm{~b}$ & $10.5 \pm 5.6 c$ \\
\hline Tribune & $0.0 \pm 0.0 \mathrm{~b}$ & $0.0 \pm 0.0 \mathrm{~b}$ & $0.0 \pm 0.0 \mathrm{~b}$ & $0.1 \pm 0.1 b$ & $6.6 \pm 2.6 \mathrm{c}$ \\
\hline Tsunami DQ & $0.2 \pm 0.2 \mathrm{~b}$ & $0.0 \pm 0.0 \mathrm{~b}$ & $0.0 \pm 0.0 \mathrm{~b}$ & $0.6 \pm 0.3 b$ & $5.7 \pm 4.3 c$ \\
\hline Weedtrine-D & $0.1 \pm 0.0 \mathrm{~b}$ & $0.0 \pm 0.0 \mathrm{~b}$ & $0.0 \pm 0.0 \mathrm{~b}$ & $0.7 \pm 0.4 \mathrm{~b}$ & $33.6 \pm 8.1 b$ \\
\hline
\end{tabular}

a Pre-treatment weights for giant salvinia trials 1 and 2 were 19.2, 20.2, and, respectively, while pre-treatment weights were 39.8, 52.1, and 48.3, for water lettuce trials 1,2 , and 3, respectively.

b Giant salvinia trials 1 and 2 were conducted during the winter, while giant salvinia trial 3 and the water lettuce trials were conducted during the growing season (spring or summer).

c Water lettuce trial 3 was harvested one week after treatment.

All triclopyr herbicides resulted in rapid leaf twisting (epinasty) of water hyacinth within 1 DAT and rapid plant control thereafter in the initial and repeat trials. All triclopyr products provided $100 \%$ control at three WAT (Table 5). Triclopyr was evaluated at a relatively high rate (1682.1 $\mathrm{g}^{\mathrm{a} . e .} \mathrm{ha}^{-1}$ ) against water hyacinth in both trials. Direct comparison of products at lower rates $\left(\leq 841 \mathrm{~g}^{\text {a.e. }} \mathrm{ha}^{-1}\right)$ should be evaluated in future studies to determine if efficacy differences can be quantified among the products. 
Table 5. Efficacy (mean $g$ dry weight, \pm SE) of generic and proprietary aquatic glyphosate brands against giant salvinia and water hyacinth eight weeks after treatmenta.

\begin{tabular}{|l|l|l|l|l|l|}
\hline & $\begin{array}{c}\text { Giant Salvinia } \\
\text { Trial 1 }\end{array}$ & $\begin{array}{c}\text { Giant Salvinia } \\
\text { Trial 2 }\end{array}$ & $\begin{array}{c}\text { Water Hyacinth } \\
\text { Trial 1 }\end{array}$ & $\begin{array}{c}\text { Water Hyacinth } \\
\text { Trial 2 }\end{array}$ \\
\hline & \multicolumn{4}{|c|}{ Rate (g a.e. ha-1 $)$} \\
\hline Herbicideb & \multicolumn{2}{|c|}{3364.1} & \multicolumn{2}{c|}{2242.8} \\
\hline Control & $110.0 \pm 5.9 \mathrm{ac}^{\mathrm{c}}$ & $63.0 \pm 6.7 \mathrm{a}$ & $235.8 \pm 13.9 \mathrm{a}$ & $171.0 \pm 18.3 \mathrm{a}$ \\
\hline Rodeo & $10.5 \pm 4.7 \mathrm{~b}$ & $2.1 \pm 1.6 \mathrm{~b}$ & $13.2 \pm 6.3 \mathrm{~b}$ & $32.8 \pm 5.0 \mathrm{bc}$ \\
\hline Roundup Custom & $14.2 \pm 2.9 \mathrm{~b}$ & $2.1 \pm 1.3 \mathrm{~b}$ & $8.4 \pm 3.6 \mathrm{bc}$ & $30.8 \pm 2.7 \mathrm{bc}$ \\
\hline AquaNeat & $8.9 \pm 2.4 \mathrm{~b}$ & $0.5 \pm 0.4 \mathrm{~b}$ & $3.9 \pm 2.6 \mathrm{bc}$ & $43.3 \pm 7.8 \mathrm{~b}$ \\
\hline AquaPro & $7.3 \pm 2.1 \mathrm{~b}$ & $0.7 \pm 0.4 \mathrm{~b}$ & $8.9 \pm 3.8 \mathrm{bc}$ & $14.2 \pm 4.2 \mathrm{c}$ \\
\hline Glyphosate 5.4 & $6.1 \pm 2.5 \mathrm{~b}$ & $3.8 \pm 1.4 \mathrm{~b}$ & $0.4 \pm 0.4 \mathrm{c}$ & $22.7 \pm 6.9 \mathrm{bc}$ \\
\hline Refuge & $5.8 \pm 1.6 \mathrm{~b}$ & $5.8 \pm 3.2 \mathrm{~b}$ & $5.9 \pm 1.7 \mathrm{bc}$ & $25.0 \pm 6.5 \mathrm{bc}$ \\
\hline
\end{tabular}

a Pre-treatment weights for giant salvinia trials 1 and 2 were 33.9 and $29.1 \mathrm{~g}$, respectively, and pre-treatment weights were 40.7 and 96.9, for water hyacinth trials 1 and 2 , respectively.

b All herbicides applied at $1598.0 \mathrm{~g}$ a.e. ha $^{-1}$.

c Means within a column followed by the same letter are not significantly different according to Fisher's Protected LSD at $p \leq$ $0.05 ; n=5$.

Table 6. Efficacy (mean g dry weight, \pm SE) of generic and proprietary aquatic triclopyr brands against water hyacinth three weeks after treatmenta.

\begin{tabular}{|l|c|c|}
\hline Herbicide $^{\mathrm{b}}$ & Trial 1 & Trial 2 \\
\hline Control & $139.0 \pm 5.9 \mathrm{a}^{\mathrm{c}}$ & $183.2 \pm 14.1 \mathrm{a}$ \\
\hline Renovate 3 & $0.0 \pm 0.0 \mathrm{~b}$ & $0.0 \pm 0.0 \mathrm{~b}$ \\
\hline Garlon 3A & $0.0 \pm 0.0 \mathrm{~b}$ & $0.0 \pm 0.0 \mathrm{~b}$ \\
\hline Triclopyr & $0.0 \pm 0.0 \mathrm{~b}$ & $0.0 \pm 0.0 \mathrm{~b}$ \\
\hline Trycera & $0.0 \pm 0.0 \mathrm{~b}$ & $0.0 \pm 0.0 \mathrm{~b}$ \\
\hline
\end{tabular}

a Pre-treatment weights for trials 1 and 2 were 72.3 and 72.2 g, respectively,

b All herbicides applied at $1682.1 \mathrm{~g}$ a.e. ha-1.

c Means within a column followed by the same letter are not significantly different according to Fisher's Protected LSD test at $\mathrm{p} \leq 0.05 ; \mathrm{n}=5$. 


\section{Conclusions}

A total of 24 products were evaluated in these trials, and the results demonstrated that the majority of the herbicides provided similar control, regardless of active ingredient or foliar application rate. Previous aquatic (Koschnick et al. 2003; Bultemeier et al. 2009; Turnage et al. 2015), row crop (Cadenhead et al. 2007; Siekman and Sandell 2008;), and roadside (McFalls et al. 2015) research also found little to no differences in efficacy between generic and proprietary clopyralid, copper, glyphosate, metsulfuron-methyl, and triclopyr. The current small-scale trials and results are a necessary starting point for developing reliable operational guidance for direct comparisons among generic and proprietary products. Although these results did not indicate any appreciable differences among products, except for glyphosate vs. water hyacinth and giant salvinia, field verification of these small-scale evaluations will refine recommendations for use in large-scale operational settings. 


\section{References}

Bultemeier, B. W., A. Puri, W. T. Haller, and V. V. Vandiver. 2009. Residue profile and efficacy comparisons between two liquid formulations of fluridone. Journal of Aquatic. Plant Management 47:63-65.

Cadenhead, J. F., C. R. Hart, R. K. Lyons, A. McGinty, B. Rector, T. Ball, E. Zimmerman, M. Palmer, R. Scott, T. Franke, and J. Hanselka. 2007. Generic herbicide efficacy for mesquite management 2007. Goldmine Applied Research Progress Report, Texas AgriLIFE Research and Extension Center. http://agrilifecdn.tamu.edu/stephenville/files/2011/02/2007Mesquite-IPT-genericAlbaugh06.pdf.

Getsinger, K. D., E. Dibble, J. H. Rodgers Jr., and D. Spencer D. 2014. Benefits of controlling nuisance aquatic plants and algae in the United States. CAST Commentary QTA2014-1. Ames, IA: Council for Agricultural Science and Technology.

Hinklin, B. A., J. A. Kendig, P. M. Ezell, and G. A. Ohmes. 2002. Chevrolet, ford, or dodge glyphosate. In Proceedings, $54^{\text {th }}$ annual meeting, Southern Weed Science Society, Biloxi, MS.

Koschnick, T. J., W. T. Haller, V. V. Vandiver, and U. Santra. 2003 Efficacy and residue comparisons between two slow-release formulations of fluridone. Journal of Aquatic Plant Management 41:25-27.

Langeland, K. A., O. N. Hill, T. J. Koschnick, and W. T. Haller. 2002. Evaluation of a new formulation of reward landscape and aquatic herbicide for control of duckweed, waterhyacinth, waterlettuce, and hydrilla. Journal Aquatic Plant Management 40:51-53.

Latiff, M. R., M. A. Arbain, and C. C. Tey CC. 2009. Efficacy of generic herbicides of glyphosate, glufosinate ammonium and metsulfuron methyl for weed control in oil palm. In PIPOC International Palm Oil Congress.

LSU AgCenter. 2017. Louisiana Agriclimatic Information System. (Accessed on 13 June 2019). http://weather.Isuagcenter.com/Default.aspx.

McFalls, J., Y. Yi, M. Li, S. Senseman, and B. Storey. 2015. Evaluation of Generic and Branded Herbicides: Technical Report. FHWA/TX-15/0-6733-1. College Station, TX: Texas A\&M Transportation Institute.

Mudge, C. R. 2007. Characterization of Flumioxazin as an Aquatic Herbicide. Ph.D. dissertation. Gainesville, FL: University of Florida.

Mudge, C. R., A. J. Perret, and J. R. Winslow. 2016. Evaluation of foliar herbicide and surfactant combinations for control of giant salvinia at three application timings. Journal of Aquatic Plant Management 54:32-36.

Mudge, C. R., and B. T. Sartain. 2018. Influence of winter on herbicide efficacy for control of giant salvinia (Salvinia molesta). Journal of Aquatic Plant Management 56:68-71. 
Nelson, L. S., J. G. Skogerboe, and K. D. Getsinger. 2001. Herbicide evaluation against giant salvinia. Journal of Aquatic Plant Management. 39:48-53.

Netherland, M. D. 2014. Chemical control of aquatic weeds. In Biology and Control of Aquatic Plants: A Best Management Practices Handbook. $3^{\text {rd }}$ ed. Marietta, GA: Aquatic Ecosystem Restoration Foundation.

Netherland, M. D, and K. D. Getsinger. 2018. Scaling studies for submersed aquatic plant management research. Journal of Aquatic Plant Management 56s:10-16.

Netherland MD, Jones KD. 2012. Registered herbicides and improving their efficacy on aquatic weeds. Aquatics 34(3):12-15.

Poovey, A. G., J. G. Skogerboe, and K. D. Getsinger. 2004. Efficacy of AVAST! ${ }^{\circledR}$ Fluridone Formulation Against Eurasian Watermilfoil and Nontarget Submersed Plants. ERDC/EL TR-04-9. Vicksburg, MS: U. S. Army Engineer Research and Development Center.

Siekman, D., and L. Sandell 2008. Comparing generic versus name brand herbicides. Lincoln, NE: University of Nebraska-Lincoln. (Accessed on 13 June 2019). https://cropwatch.unl.edu/comparing-generic-versus-name-brand-herbicides.

Turnage, G., J. D. Madsen, and R. M. Wersal 2015. Comparative efficacy of chelated copper formulations alone and in combination with diquat against hydrilla and subsequent sensitivity of American lotus. Journal of Aquatic Plant Management 53:138-140.

University of Florida. 2018. Plant management in Florida waters: an integrated approach. Details about the aquatic herbicides used in Florida. Gainesville, FL: University of Florida. (Accessed on 16 June 2019). http://plants.ifas.ufl.edu/manage/controlmethods/details-about-the-aquatic-herbicides-used-in-florida.

United State Environmental Protection Agency (USEPA). 2017. Registration review process. (Accessed on 16 June 2019). https://www.epa.gov/pesticide-

reevaluation/registration-review-process. 
The public reporting burden for this collection of information is estimated to average 1 hour per response, including the time for reviewing instructions, searching existing data sources, gathering and maintaining the data needed, and completing and reviewing the collection of information. Send comments regarding this burden estimate or any other aspect of this collection of information, including suggestions for reducing the burden, to Department of Defense, Washington Headquarters Services, Directorate for Information Operations and Reports (0704-0188), 1215 Jefferson Davis Highway, Suite 1204, Arlington, VA 22202-4302. Respondents should be aware that notwithstanding any other provision of law, no person shall be subject to any penalty for failing to comply with a collection of information if it does not display a currently valid OMB control number. PLEASE DO NOT RETURN YOUR FORM TO THE ABOVE ADDRESS.

\section{\begin{tabular}{l|l} 
1. REPORT DATE & 2. REPORT TYPE
\end{tabular} \\ September 2019 \\ Final}

\section{TITLE AND SUBTITLE}

Comparison of Generic and Proprietary Aquatic Herbicides for Control of Invasive

Vegetation: Part 1. Floating Plants

\section{AUTHOR(S)}

Christopher R. Mudge and Kurt D. Getsinger

\section{DATES COVERED (From - To)}

5b. GRANT NUMBER

5c. PROGRAM ELEMENT NUMBER

5d. PROJECT NUMBER

462030

5e. TASK NUMBER

5f. WORK UNIT NUMBER

\section{PERFORMING ORGANIZATION NAME(S) AND ADDRESS(ES)}

U.S Army Engineer Research and Development Center

Environmental Laboratory

3909 Halls Ferry Road, Vicksburg, MS 39180-6199

\section{SPONSORING/MONITORING AGENCY NAME(S) AND ADDRESS(ES)}

10. SPONSOR/MONITOR'S ACRONYM(S)

Headquarters, U.S. Army Corps of Engineers

Washington, DC 20314-1000

11. SPONSOR/MONITOR'S REPORT

NUMBER(S)

HQUSACE

\section{DISTRIBUTION/AVAILABILITY STATEMENT}

Approved for public release; distribution is unlimited.

\section{SUPPLEMENTARY NOTES}

\section{ABSTRACT}

Herbicides are one of the most effective and widespread ways to manage nuisance aquatic vegetation in the U.S. After the active ingredient is selected, often there are multiple proprietary and generic branded products to choose from. Limited research has been conducted to compare the efficacy of these herbicides head to head. Therefore, a series of mesocosm trials were conducted to evaluate 2,4 D, glyphosate, diquat, and triclopyr against the floating species giant salvinia, water hyacinth, and water lettuce. All active ingredients were applied to the foliage at broadcast rates commonly used in applications to public waters. Visual observations indicated that all herbicides within a particular active ingredient performed similarly with regard injury symptoms. There were no significant differences in product performance with regard to 2,4-D vs. water hyacinth, diquat vs. water lettuce, glyphosate vs. giant salvinia, and triclopyr vs. water hyacinth. Although statistical differences in performance of products were detected in the diquat vs. water lettuce (trial 3 ) and both glyphosate vs. water hyacinth trials, these differences were not consistent across initial and repeated trials. These results demonstrated that under outdoor mesocosm conditions, the majority of the generic and proprietary herbicides provided similar control, regardless of active ingredient or rate.

\section{SUBJECT TERMS}

Aquatic plants--Effects of herbicides on Invasive plants--Effects of herbicides on Aquatic herbicides--Evaluation

\section{SECURITY CLASSIFICATION OF:}

\begin{tabular}{|l|l|ll|} 
a. REPORT & b. ABSTRACT & c. & THIS PAGE \\
Unlimited
\end{tabular}

\section{Unlimited}

17. LIMITATION OF
ABSTRACT
SAR
OF PAGES 19a. NAME OF RESPONSIBLE PERSON

19b. TELEPHONE NUMBER (Include area code) 